\title{
Tarihsel Süreç İçerisinde Üslüba İlişkin Tanım Çabaları ve Bir Tanım Denemesi (I)
}

CELALETTIN DIVLEKCI

AR. GÖR., ANKARA Ü. SOSYAL BILIMLER ENSTITÜSÜ

e-posta: cdivlekci@hotmail.com

\begin{abstract}
A Survey of the Definitions for Style and a Suggestion for a New One. This study deals with the definitions of style both in the Western and Islamic literature and has the aim of having a definition within this frame. Style definitions in the Western literature are divided and taken into consideration as old and modern approaches. With respect to modern approach, we divided the definitions in three sub categories as author-centred definitions; reader-centred definitions; work-centred definitions. Definition efforts in the Islamic culture are analyzed under two sub-categories as classic period and modern period.
\end{abstract}

key words

Definition of style, Style in the Western Literature, Style in the Islamic Literature.

\section{GiRiş}

Üslûp terimi, modern araştırmalarda yer aldığı kadar dil ve edebiyatla ilgili pek çok konuyla irtibatlı üstelik gündelik hayatımızda da sıkça kullandığımız bir terimdir. Daha açık bir ifadeyle üslûbun kullanım alanı sadece edebî eserlerle sınırlı olmayıp, dilin iletişim işlevini üstlendiği, bütün bireysel ve toplumsal alanları da içine alacak genişliktedir. Üslûp, daha ilk çağlardan beri eşzamanlı ve art zamanlı boyutları ile tartışılan ve teorisinden çok pratik olarak kullanılan ifade sanatı olarak karşımıza çıkmaktadır. ${ }^{1}$

İlk çağlardan beri tartışılmasına ve pratik olarak kullanılmasına rağmen ortada net, sınırları çizilmiş bir tanımdan söz etmek mümkün gözükme-

1 Karakaya, Zeki, "Üslûp ve Üslûpbilim Kuramları”, Akademik Açı, 1996, S. 2, s. 117. 
mektedir. Bilhassa Türkçe literatürdeki izahların derinlik bakımından kavramın edebiyat ve gündelik hayattaki yeriyle mütenâsip olduğunu söylemek oldukça güçtür. ${ }^{2}$ Türkçe Sözlüklerdeki bu yüzeyselliğin yerini, ilmî değeri hâiz çağdaş eser(ler)de ise, kendi içinde tutarlı bir suskunluk almaktadır. ${ }^{3}$ Söz konusu durum sözlük bağlamında İslamî literatüde de çok fark11 değildir. Arap Dili'nin 'Lisanü'l-Arab' ve 'Sthah'4 gibi devasa sözlükleri başka kavramlarda gösterdikleri cömertliği bunda göstermezler. Oysa ki Batı dillerinde, (Örneğin İngilizce'de Oxford gibi sözlüklerde) hayranlık veren bir tanım titizliği ve zenginliğine şahit olmaktayız. ${ }^{5}$ Buna rağmen üslûp kavramının sözlüklerle iktifâ edilemiyek kadar vüsatli bir mefhum olduğunu düşünmekteyiz.

Bu çerçevede Batı Düşüncesindeki tanım çabalarını yazar merkezli, eser merkezli ve okur merkezli şeklinde bir tasnifle ele alırken, İslam Düşüncesindeki tanım çabalarını, klasik dönem ve modern zamanlar başlıkları altında kronolojik olarak ele almayı tercih ettik. İki farklı kültürün tanım çabaları arasındaki çarpıcı benzerliklere de temas etmeden geçmek istemedik.

Düşünce ve edebiyat dünyamızda böylesine önemli bir kavramı vuzuha kavuşturmadan yapılacak her atıf yahut tartışmanın ilmî anlamda eksik ve yetersiz olacağından, üslûbun tanıma giden yolda mütevazı de olsa bir adım atıp bir tanım denemesinde bulunduk. Yapmış olduğumuz tanım denemesinde, adı geçen kültürlerle bağlantı kurmak gibi çaba içine de girmedik.

\section{A. Batida}

Batı Dünyasındaki yaklaşımlara geçmeden önce, kelimenin sözlüklerdeki sicil kaydına kısaca göz atmakta fayda görüyoruz. Üslûp kelimesinin Batı Dillerinden İngilizce'deki karşılı̆̆ 'style'; Eski Fransızca'daki karşıllı̆̆1, 'style' ve 'stile'; Almanca'da ise 'stil' şeklindedir.

2 Bkz. Karataş, Turan, Edebiyat Terimleri Sözlüğü, Akçağ Yay., Ankara 2004, s. 499, 500.

3 Üslûp konusunda Türkçe'de yapılmış en ciddi ve maalesef tek çalışma Şerif Aktaş'a ait 'Edebiyatta Üslûp ve Problemleri' adlı eserdir. 'Kendi içinde tutarlı suskunkuk' derken müellifin, gelişme merhalesinde bulunan bir kavramı bir tanıma sığdırmanın kimsenin hakkı olmayacağına dair yapmış olduğu atfı kast etmekteyiz. Bkz. Aktaş, Şerif, Edebiyatta Üslûp ve Problemleri, Akçă̆ Yay., Ankara 1986, s. 9, 10.

4 Bkz. İbn Manzur, Ebû'l-Fadl Cemalüddin Muhammed b. Mükerram, Lisânu'l-Arab, Beyrut 1990, (s-l-b) maddesi; el-Cevherî, İsmail b. Hammâd, es-Sthâh tâcü'l-lüga ve sthâhu'l-Arabiyye, Tahk. A. Abdülgaffâr Atar, Beyrut 1990, (s-l-b) maddesi.

5 Adı geçen ve 10 cildi aşkın olan sözlükte kavrama, küçük punto ile yedi sütun; üç sayfa halinde yer ayrılmış ve titiz bir semantik analiz örneği sergilenmiştir. Bkz. The Oxford English Dictionary, Oxford 1933, X. 1205-1207. 
İngilizce'de style kelimesi, Latince, kazık yahut yazmak için ucu sivri alet anlamına gelen 'stilus' kelimesinden gelmektedir. Orta Dönem İngilizce'sine ait olan kelimenin ${ }^{6}$, Antik dönemde, "balmumundan tabletlere yazı yazmak için bir sivri ucu ve yazllanları silmek ya da düzeltmek için bir de düz ucu bulunan metal, kemik ve benzeri maddelerden yapılan alet" anlaminda kullanıldığı XIV. üncü yy.a ait metin kanıtlarından anlaşılmaktadır.

Kelimenin XIV. yüzyılda sahip olduğu anlamlar, ikisi somut diğer ikisi soyut olmak üzere dört temel grupta toplanmaktadır: Yazı aleti, yazma/ yazım şekli, moda/tarz ve tarihleri belirtme şekli. Kelimenin diğer anlam gruplarını bir tarafa bırakıp, konumuzla, edebiyatla ilgili olan soyut anlamı üzerinde, ilgili metin kanıtlarıla birlikte bir gezinti yapalım.

XIV.yy.ın başlarında, "yazılı metin veya metinler, edebî telif, daha sonraki kullanimlarda söz ya da güfte telifi, anlamindadır": "The style o matheu, water it was, And win the letter o lucas." Cursor M. (1300). (Mathew'un yazdıkları su gibiydi ve Lucas'tan bir mektupla ödüllendirildi.) Metin ve edebî telif anlamının yanı sıra, "bir yazarın ya da edebî bir grubun ya da dönemin üslûbu, bir yazarın açılılk, etkileyicilik, güzellik vb. açllardan tarzı." anlamında kullanılmaya başlar: "On frankis stile this storie wrote." R. Brunne Chron, (1330). (Bu hikaye Frenk üslûbuyla yazılmıştır.)

XV. yy.'a gelindiğinde, 'bir şeyi resmi yazıya dökmek için kullanılan biçim, sözcük dizini” (1480) gibi bir anlamla karşımıza çıkar. Oxford, bu yüzyıl boyunca kelimenin yeni bir soyut anlam kazandığına dair bir kayıt vermez.

XVI. yy. başlarında, kitâbe veya efsane anlamı dikkat çeker: "And a Stil on the Hede of every Quarter of the Parcellis that is provided forre." (1512) Earl Northumb. (Ve parselin her köşesinde bir kitâbe.) Bu yüzyılda konumuz açısından asıl önemli olan anlamı, "gündelik konuşmalarda muhatap kişiyle iletişim kurmakta kullanılan söylem, konuşma biçimi." şeklindeki anlamıdır: "Stop vp thine Syren to beguile,.. be sure To lend no eare vnto hir flattring stile" (1567) Turber. (Kulaklarınızı kapatın bu Siren'in söylediklerine, onun boş övgülerle dolu üslûbunu duymayın sakın.) İlaveten, "yasal bir belgenin girişi ya da bir bölümü. Ayrıca bir vasiyetin, yazının, herhangi bir belgenin başlığı ve standart girişi.” (1570-6) resmi yazılardaki standart kalıp anlamı da söz konusudur.

Kelime aynı yüzyılın üçüncü çeyreğinde, "genel anlamda, edebi yapttların içeriğinden çok biçimine yönelik özellikler. Genelde iyi, güzel üslûp şeklinde kullanılı": "I neuer made any choise od stile, or picked wordes." (1577)

6 Little, William, Fowler, H. W., Coulson, J., The Shorter Oxford English Dictionary; on Historical Principles, (Revised and edited by C. T. Onions), London 1955 II. 253. 
Harrison. (Herhangi bir stilde, sözcükleri seçerek yazmadım.) İyi seçim, güzel üslûp, anlamı da yine bu yüzyılda 'style'a eklenir: "All this is but bad English, when wilt thou come to a stile?" (1589) Pappe w. Hatchet. (Bunların hepsi kötü İngilizce, ne zaman iyi bir üslûp edineceksin kendine?)

XVI. yy.ın sonlarına gelindiğinde, "belli bir düşüncenin, fikrin ifade edildiği kelime, ifade, cümle biçimleri." anlamında kullanılacaktır: "Neuerthelesse wee meane according to stile of the holy scriptures, that hee." (1594) T. B. (Biz yine de Kutsal kitabın stilini, O'nun stilini kullanıyoruz.)

XVII. yy.da, muhtemelen Latince'den bir deyimin;"Stylus virum arguit." R. Burton (1624). (Üslûbumuz bizi ele verir.) İngilizce'ye aktarılması sonucu, üslûp demek insan demektir, anlamında "The style is the man" tabiri dile yerleşir. Deyim şöhrete kavuşmak için Buffon'un 1753'te verdiği meşhur nutkunda "Le style c'est l'homme même" (Üslûp demek insan demektir.) demesini bekleyecektir.

XVII. yy.1n ortalarında ise, "genel anlamda, dilin ya da yapının kelimeler ve üslûp cümlelerindeki meşru niteliği," anlamında da kullanılır: "The extent of the obligation is to be gathered from the nature the transaction, rather than from clauses of style slightly or imperfectly framed." Kames (1743). (Yükümlülüğün çapı, zayıf ya da kusurlu bir şekilde kurulmuş üslûp cümlelerinden çok, işin tabiatından çıkartılmalıdır.)

XIII.yy.ın başlarında kelimenin edebiyattaki kullanımı sanata bilhassa mimariye yansır. "Vasıflı yapı, uygulama ve üretim yöntemi. Bir sanat eserinin belli bir sanatçıya ait olduğunu, o sanatçının yaşadı̆̆ yer ve dönemi belirten özellikler, güzel ve nitelikli eserin üretilebilmesi için gerekli görülen tarzlar." "Style, in Music, the manner of Singing and Composing. Thus we say, the style of the Charissimi, of Lully, of Lambert; the Style of the Italians, the French, the Spaniards."(1728) Chambers. (Üslûp müzikte, şarkı söyleme ve beste yapma tarzıdır. Bu anlamda Charissimi, Lully ya da Lambert üslûbundan, İtalyan, Fransız, İspanyol tarzından söz edebiliriz.); "On Columns, rais'd in modern Style." (1743) Francts tr. (Modern stilde yükseltilmiş kolonlar.)

Bu yüzyılın sonlarına doğru, "yapı ve süslemeleriyle ayırt edilen belli bir mimari biçimi," anlamı, üslûbun sanat alanındaki diğer kullanımlar arasındaki yerini alır. Bu anlamda çeşitli sınıflandırmalar yapılır: Yunan, Gotik, İtalyan, Roma stili, Normandiya, Erken Dönem İngiliz, Süslü, Dik, Tudor, Rönesans, Palladio stili gibi: "A very handsome church..in the Gothic stile" Dalrymple (1777). (Çok güzel bir kilise... Gotik üslûbunda.) ${ }^{7}$

7 The Oxford English Dictionary, Oxford 1933, X. 1205-1207. Metin kanıtlarını aktarırken orta 
Üslûbun İngiliz Dili'ndeki bu anlam ve kullanımlarından bir kısmı artık eskimişken, diğer bir kısmı XIX.uncu ve XX.yy.da da devam etmiştir. Üslûp kelimesinin doğuşu gelişimi ve yüzyıllara göre kazandığı anlamların bir çerçevesini çizmeye çalıștık. Şimdi de konunun Batı Edebiyat Tarihinde bir edebiyat terimi ve konsepti olarak, kadim ve modern dönemlerdeki tezahürlerini inceleyelim.

\section{Kadim Yaklaşım}

Batıdaki üslûp anlayışı ve üslûp incelemelerinin kökenine bakıldığı zaman, üslûp kavramının, Avrupa'daki edebî düşüncenin başlangıç safhalarına kadar geriye uzanan eski bir kavram olduğu görülür. O dönemde üslûp, şiirden ziyade retorikle ${ }^{8}$ bağlantılı gibi görünür; ancak üslûbun ikna tekniğinin bir parçası olarak algılanması ve sonuç olarak da hitabet başlığı altında incelenmesi dışında bu durumun özel bir nedeni yoktur. Antik dönemdeki retorik; törensel, politik ve hukuki hitabet olarak üçe ayrılmıştı ve her bir hitabet türünün kendine uygun aracı ve uygun enstrüman listesi vardı. Özel bir etki oluşturmak istediğinizde, bu etkiyi oluşturmaya vesile olacak ve amacınızı gerçekleştirmede kullanılacak araçlar şunlardı: Uygun kelime haznesi, söz dizimi (sentaks) ve edebi sanatlar. Bu antik retoriğin tutumu; uygun ve etkili bir inşa için teknik bilgi vermek şeklinde açıklayabileceğimiz oldukça kuralcı bir tutumdu. ${ }^{9}$

"Antik dönemdeki retorik, sonraki evrelerinde bu tartışmayı tarihçilere ve diğer nesir yazarlarına kadar genişletme eğiliminde olmuştur. Ortaçă̆da ve Rönesans döneminde retoriğin temel kaidelerine ilişkin bu muazzam talimat/prensip, sadece eleştirel düşünce üzerinde değil, aynı zamanda -son zamanlardaki araştırmaların ortaya koyduğuna göre- bizzat şiir inşası üzerinde de derin bir etki bırakacak şekilde poetikaya (şiir teorisine) geniş ölçüde dahil edilmişti. Bu gelenek, 18. yüzyıla kadar varlığını sürdürmüştür."

dönem İngilizce'sine ait yazım şekli ve farklılıkları olduğu gibi koruduk, sadece 'th' sesini göstermek için kullanılan '̈̈’ işareti yerine günümüz İngilizce'sindeki yazım șeklini kullandık.

8 Makale boyunca retorik ve belagat kavramlarının kullanışında ayrıma gitmenin ilmî esaslara daha uygun olacağını düşündük. Zira her iki kavramın söz söyleme sanatına yaklaşımları farklı olduğu gibi, ait oldukları kültürdeki tarihsel maceraları da kaçınılmaz olarak farklı olmuştur. O yüzden Batı Edebiyatı ve kültürü söz konusu olduğunda "retorik"; İslam Edebiyatı ve kültürü söz konusu olduğunda ise "belagat"; her iki kültürün kesiștiği bir bağlam söz konusu olduğun da ise, her iki terimi "retorik ve belagat" şeklinde müteakiben kullanmayı tercih ettik. Türk Edebiyatı XIX. yüzyılın ikinci yarısına kadar belagatın etkisinde kalmış, bu tarihten itibaren, toplumsal değişimin bir sonucu olarak Türk Edebiyatında da retoriğe doğru bir yöneliş gözlenmiştir. Genis bilgi için bkz. Yetiş, Kâzım, Belâgattan Retoriğe, Kitabevi, İstanbul 2006.

9 Hough, Graham, Style and Stylistics, London 1969, s, 1. 
"Yine de ortada kolayca gözden çlkarılamayacak eski retoriğin üslûp anlayışına dair başka miraslar da vardır. Geleneksel retorik ve tenkitte, içerikle biçim; söylenen şeyle söyleyiş tarzı arasında ayrım yapmamak esastı. Bu tür şeyler, beklide son derece gerekli olarak, genellikle metafor şeklinde dile getirilirdi. Dilden bahsederken en yaygın kullanılan benzetme, dilin düşüncenin elbisesi olduğu şeklindeki benzetmedir. Düşüncenin kelimenin dile gelmeden önceki biçiminde var olduğu farz edilir ve düşünce, sonrasinda dile giydirilir. Bu teoriye bakarak üslubun ne olduğunu anlamak kolaydır. Dil, düşüncenin elbisesidir ve üslûp, elbisenin tam ve ona uygun kesilmiş şeklidir. "10

"Bu tarz bir düşünme şekli birtakım sonuçları da beraberinde getirir. Uygun kesim ifadesine farklı açılarından bakılabilir. Dryden (d.1631-ö.1700) ${ }^{11}$ bunu konunun dikte ettirdiği bir şey olarak görür; düşünce 'konuya uygun' bir biçimde çekip çıkarılmalıdır; kelimeler konuya 'uygun' seçilmelidir. Bu anlayış, edebiyattaki neo-klasik teoriyle tam manasıyla örtüşmektedir. Her edebî türün kendine has bir üslûbu vardır; trajedinin üslûbu pastoral şiirin üslûbuyla aynı olmayacaktır çünkü ikisinin de konuları farklıdır ve bu durum, yazarın kendine özgü beğenilerinden ziyade tamamıyla nesnelerin tabiatıyla ilgili bir durumdur. Nispeten daha geç bir tarihte, edebiyat teorilerinin gelişmesiyle birlikte, üslûp yazarın tabiatının dikte ettirdiği/oluşturduğu bir kavram olarak görülür olmuştur. Üslûp, yazarın kişiliğinin bir ifadesidir. Buffon'un meşhur sözü: Le style c'est l'homme même (Üslûb-u beyân ayniyle insandır.) Bu yaklaşımı genişletecek olursak, belli bir dönemin ya da bir edebiyat ekolünün üslûbundan bahsederek devam edebiliriz. Romantik şairlerin üslûbu Pope ekolü şairlerinin üslûbundan aynı şeyi farklı biçimlerde söyledikleri için mi yoksa farklı şeyler söyledikleri için mi farklıdır? Büyük ihtimalle ikincisidir ve bunun üzerinde ne kadar fazla düşünürsek, farklı söyleme şekilleri üzerine ne kadar konuşabileceğimiz konusu bir o kadar şüpheli hale gelir; her bir farklı söyleme şekli aslında farklı bir şeyi söyleme değil midir?" 12

Bu konuya dair tefekkür süreci Hough'a göre, 18. yüzyıl boyunca aralıklarla devam etmiştir. ${ }^{13}$

"Bloomfield, ${ }^{14}$ 'Bilimin Dilbilimsel Yönleri' üzerine kaleme aldığı bir makalede şöyle der: 'Biçim olarak farklı ifadelerin her zaman farklı anlamla-

10 Hough, Style and Stylistics, s. 2, 3.

11 Dryden (d.1631-ö.1700). Yazar, şair ve tiyatro eleştirmeni. İngiliz Eleştirisinin babası kabul edilir. Bkz. Halil, İbrahim, el-Üslûbiyye ve nazariyyeti'n-nass, Dâru'l-fâris, Amman 1997, s. 83. (2.inci dipnot)

12 Hough, Style and Stylistics, s. 3, 4.

13 Hough, Style and Stylistics, s. 4.

14 Leonard Bloomfield (d.1887-ö.1949) Amerikan yapısalcılığının kurucusu ABD.'li dilbilimci. 
ra gelmesi hususu, iyi test edilmiş dilbilimsel bir hipotezdir.' Üretken gramer alanındaki son gelişmeler, bu durumun en azından şüpheli olduğunu gösterir ve eşanlamlılığın konumu hâlâ tartışmaya açıktır. Ancak Bloomfield'in bakış açısı geneldir. Bu hipotezde aynı düşünceyi farklı biçimlerde ifade etmekten değil sadece farklı düşüncelerden bahsedebiliriz. Bu durumda üslûp denen bir şeyden söz etmek mümkün müdür? Bu durum Richard M. Ohmann ${ }^{15}$ tarafından çok açık bir biçimde dile getirilmiştir:

'Eğer üslûbûn, tenisteki stilin topa vuruş şekilleriyle olan alakasina benzer türde, bir şeyi ifade etme yollartyla bir alakası yoksa, o zaman ortada 'üslûp' olarak adlandırlmaya değer bir şeyden söz edilebilir mi? Eleştirmen yazarın ne dediği hakkında konuşabilir, fakat üslûbu hakkında konuşamaz çünkü -tek düşünce, tek biçim şeklinde tezahür eden- düzenli mizacı bireysel farklılı̆̆a yer birakmaz. Bu bireysel farklılık, tam da bizim genel olarak üslûp la kastettiğimiz şeydir. Eleştirmene bu hak verildiği takdirde, üslûp işe yaramaz bir farazi yapıya dönüşür.'

Bu sebepten dolayı 'üslûp' kelimesi modern eleştirinin başat alanında çok az yer alır hale gelmiştir." 16

\section{Modern Yaklaşım}

Kelime anlamına ne olmuş olursa olsun, Batıda üslûp kavramı, uygulamada kolayca ortadan kaldırılamayacak kadar önemli olmuştur. Çünkü bir zamanlar üslûp ismi altında barınan çeşitli unsurlar/düşünceler Batı Edebiyatında hâlâ ciddi anlamda fâaldir. İngiltere ve Amerika'da, tenkit ve eğitime yönelik oldukça kompleks uygulamalar -isim vermeksizin- geniş ölçüde üslûp tahliline dayanmaktadır. 1920'lerde I. A. Richards ${ }^{17}$ tarafından

Çalışmalarını önceleri yazılı belgesi bulunmayan Kuzey Amerika yerli dilleri üzerine yoğunlaştırdı.Sözlü dil incelemelerine ağırlık verdi ve eşsüremli yöntemin Amerika'da gelişmesine katk1da bulundu. An Introduction to the Study of Language adlı eserinde Alman ruhbilimcisi W.Wundt'un etkisinde kalarak zihinsel psikolojiden yararlandı.1926'da yayımladığı bir yazısında ise bu görüșünü bırakarak, benimsediği karşı görüșün temel ilkelerini açıladı.1933'te yayımlanan Language adlı eserinde yalnızca gözlemlenebilen olguların incelenmesi gerektiğini öne sürerek, dili insan davranışının özel bir biçimi olarak gördü. Bu görüşleriyle Bloomfield Amerikan dilbiliminin öbür bilim dallarından bağımsız, kendi inceleme konusu ve yöntemleri olan müstakil bir bilim dalı durumuna gelmesini sağladı. Bloomfield'in "dağılım" kavramı, dağılımsal dilbilimin doğmasına yol açmıştır. Eserleri arasında bilhassa Language or Ideas [1936] ve Meaning [1943] sayılabilir. Geniş bilgi için bkz. Vardar, Berke, vd., Açıklamalı Dilbilim ve Dilbilgisi Terimleri Sözlüğ̈̈, İstanbul 1998, s. 51, 52.

15 İngiliz dilbilimci.

16 Hough, Style and Stylistics, s. 1-5.

17 İngiliz münekkit. Pek çok eseri vardır. Uygulamalı Edebiyat Eleştirisi'nde Psikanalitik Tahlil Ekolünün lideridir. Bkz. Halil, el-Üslûbiyye ve nazariyyeti’n-nass, s. 83. ( Yazara ait 8.inci dipnot) 
yürütülen- Amerika'da 'Yeni Eleştiri' (New Criticism) adı verilen - 'pratik eleştiri deneyleri', 'yaygın açıllama teknikleri' ve şiirde 'yakın okuma' gibi hususlar bahse konu olan kompleks uygulamalardır. ${ }^{18}$

Kısa bir parçada sergilenen özelliklerden hareketle, bir eserin tabiatının ortaya çıkarılabileceği düşüncesi hâlâ yaygındır ve bu kimilerine göre üslûba ilişkin bir dogmadır. Edebiyatın söze ilişkin (verbal) dokusuyla sıkı bir bağı olmasıyla övünen modern eleştirinin tüm bu yapısı gerçekten de bir çeşit üslûp incelemesidir.

Modern Üslûpbilimin kurucu öncülerinden biri olan Charles Bally ${ }^{19}$ üslûp incelemesini, dildeki 'etkili' (affective) unsurların incelenmesi olarak tanımlamıştır -bu etkili unsurlar, zaten anlamı belirli olan bir kelimeye, tercihe bağlı olarak yapılan eklemeler olarak düşünülmüştür. O üslûp bilgisini tüm dil sistemini tanıma kaynağı olarak görür. Bu yüzden üslûp bilgisi, dil vasıtalarının araştırılmasına, onların rasyonel ve duygusal ifade gücünün belirlenmesine yönelik olmalıdır görüşünü savunur. Bally, romanistikte gelişen üslûp bilgisinin etkisi altında kalmıştır. ${ }^{20}$

Yakın dönem araştırmacılarından Hockett ${ }^{21}$ "Course in Modern Linguistics" (Modern Dilbilimde Yöntem) adlı eserinde şunu öne sürer: "Yaklaşık olarak aynı bilgiyi taşıyan fakat linguistik yapı bakımından farklı olan aynı dildeki iki sözce, üslûp bakımından farklıdır, denilebilir: 'He came too soon' (Çok çabuk geldi) ve 'He arrived prematurely'(Erken geldi) örneklerinde olduğu gibi. Stephen Ullmann, ${ }^{22}$ Proust (d.18872-ö.1922)'un ${ }^{23}$ bir cümlesi-

18 Hough, Style and Stylistics, s. 5.

19 Charles Bally (1865-1947). İsviçreli dilbilimci. Saussure düşüncesi çerçevesinde araştırmalar yapan Cenevre Okulu'nun kurucularındandır. A. Sechehaye'le birlikte F. De Saussure'ün Cenevre Üniversitesi'nde verdiği derslerin notlarını öğrencilerinden toplayarak Course de linguistuque généraléi'i (Genel Dilbilim Dersleri) [1916] yayına hazırladı. Bally, Linguistuque généralé et inguistuque française (Genel Dilbilim ve Fransız Dilbilimi) [1932] adlı yapıtında Fransızca'nın genel anlamsal yapısını Almanca'yla karşılaştırarak belirlemiş, üslûp incelemelerinde dilin toplumsal boyutuna ağırlık veren bir yaklaşım benimsemiştir. Traité de styllistique de français (Fransızca'nın Üslûbuna İlişkin İnceleme) [1909]. Bally'nin çalışmaları hem sosyolojiye, hem de üretici dönüşümsel dilbilgisine giden yol üstünde yer alır. Bkz. Vardar, Açıklamalı Dilbilim ve Dilbilgisi Terimleri Sözlüğü, s. 36.

20 Yıldız, Cemal, Üslûp ve Üslûp İnceleme Metodlart, (Yayınlanmamış Yüksek Lisans Tezi), Marmara Üniversitesi Sosyal Bilimler Enstitüsü, İstanbul 1991, s.14.

21 Fransiz dilbilimci.

22 Stephen Ullmann, İngiliz Dilbilimcidir.1914 yılında doğdu. Romans Dilleri uzmanıdır. Anlambilim konusuna bilhassa önem verdi. Başlica eserleri: The Principles of Semantics, Semantics an Introduction to The Science of Meaning ve Précis de Sémantique Française'dir. Bkz.el-Meseddî, el-Üslûbiyye ve'l-üslûb, s. 236.

23 Marcel Proust (d.18872-ö.1922). Fransız edîbi, önce şiirle ilgilendi. Les Plaisirs et Les Jours'u neşretti. Yaşamış olduğu bazı ailevi ve sağlık sorunları nedeniyle içine kapandı. Edebiyata sı̆̆ındı. Meriç'e göre, romana iç dünyanın kapılarını açtı. Üslûbunu Ruskin tercümeleriyle olgunlaştırdı. 
ni alıntılar daha sonra onun yeniden tanzim edilmiş bir versiyonunu teklif eder ve şöyle der: 'Her iki cümle de aynı anlamı ifade eder.' Ardından iki cümle arasındaki farklılığı, tesir (effectiveness) bakımından yani belirli bir anlamın ortaya konulmasındaki tesir bakımından tahlil eder. ${ }^{24}$

Profesyonel dilbilimcilerin bu probleme yönelik tavırları bir değişim süreci içerisindedir. Chomsky'nin üretken gramer (generative grammar) alanındaki son çalışmaları şu hipoteze -ki bu hâlâ sadece bir hipotezdir- öncülük etmiştir: Farklı dillerde farklı dilbilgisel şekiller öngören cümlelerin derin yapısı, tüm dillerin anlama ilişkin everensel esasları olabilir, tek bir dildeki tek bir semantik yapı aslında farklı ancak eşanlamlı dilbilgisel şekiller öngörebilir. Eşanlamlı cümleler arasındaki farklılıklar böylelikle üslûp olarak adlandırılabilir ve bu da esasında dilin düşüncenin elbisesi olduğu yönündeki o eski görüşe dönüştür. ${ }^{25}$

Batıdaki, üslûp düşüncesi mirasının sahip olduğu birikimden, düşüncenin zaman katmanları boyutunu gösterecek dikey bir kesit aldığımız zaman, üslûp düşüncesinin epistemolojik olarak üç saç ayağı üzerine oturduğu görülecektir: Kaynak birim (yazar/konuşmac1/mesajı gönderen taraf), hedef birim (okur/muhatap/mesajı alan taraf) ve söylem (eser/ konuşma/ mesaj). Bu üçlü teorileştirmenin, genel olarak insanlık tarihinde dil düşüncesinin var olmasından itibaren var olduğu, anlaşılmaktadır. Bu üçlü sistemin, dilbilim olayının tanımında yer alan, temelleri enformasyon düşüncesine dayanan iletişim düşüncesiyle yakından bağlantılı olduğu görülmektedir. ${ }^{26}$ Buna göre her iletişim sistemi, kaynak birim, hedef birim ve kanal olmak üzere en az üç unsurdan oluşan bir sistemi gerektirir. Kaynak birim kodlama işlemini yapar yani kavram ve soyut düşünceleri, alet konumundaki dil aracilığı ile kanaldan geçecek somut bir söz dizimi içine yerleştirir. Hedef birimse, muhatap olup kaynak birimin yapmış olduğu kodlamayı çözer. ${ }^{27}$

Batıdaki üslûp tanımlarını kaynak birim/yazar merkezli tanımlar, hedef birim/okur merkezli tanımlar ve söylem/eser merkezli tanımlar olmak üzere üç kategoride incelememiz yerinde olacaktır.

a) Kaynak birim/Yazar Merkezli Tanımlar: Öncelikle davranışçı kuramın verilerine ve bu verilerin özel olarak üslûpbilim incelemelerine yaptığı kat-

19. asır romanı için Balzac ne ise, 20. asır romanı için de Proust odur. Bkz. Meriç, Cemil, Bu Ülke, İletişim Yay., İstanbul, 1992, s. 325. Krş. el-Meseddî, el-Üslûbiyye ve'l-üslûb, s. 238.

24 Hough, Style and Stylistics, s. 5, 6.

25 Hough, Style and Stylistics, s. 7.

26 el-Meseddî, el-Üslûbiyye ve'l-üslûb, s. 55. Krş. Azzâm, el-Üslûbiyye menhecen nakdiyyen, Menşûrâtu vezârâti's-sekâfe, Dimaşk 1989, s. 22.

27 el-Meseddî, el-Üslûbiyye ve'l-üslûb, s. 55; Azzâm, el-Üslûbiyye, s. 22. 
kılara işaret etmek gerekmektedir. Bloomfield (d.1887-ö.1949), davranışçı kuramdan etkilenen ilk dilbilimci olup, dilbilimi söz konusu kuramın ışığı altında felsefî ölçütlerden soyutlamaya ve onu müstakil ve tecrübi bir ilim haline getirmeye çalışmıştır. Bunun sonucu olarak dil olgusunu, sırasıyla birbirini tetikleyen bir dizi uyarıcı ve geri ileti/tepki olarak tanımlamıştır. Bloomfield (d.1887-ö.1949) bu çerçevede üslûbu, sahibinin düşünce tarzını ortaya koyacak esas şeklinde tarif eder. ${ }^{28}$

Bir de üslûbun sahibiyle özdeş hale geldiği ikinci bir şekil vardır. Üslûba tanım getirme düşüncesi; sahibinin şahsiyetine götüren bir kanal olması yönüyle üslûp, insanın sanatsal veya varlıksal anlamda şahsiyetiyle irtibatl1 hale gelmiştir. ${ }^{29}$ Bu yaklaşımı, üslûbu insanın kendisi olarak gören Buffon (d.1708-ö.1788) sergilemiştir: "Bilgiler, olaylar ve orijinal buluşlar, zamanla yok olup gidebilir veya başka bir şeye dönüşebilirler. Hatta çoğu zaman daha usta bir elde daha rafine hale gelir. Bütün bu öğeler insanın dışında kalan şeylerdir. Oysa üslûp insanın tâ kendisidir; ne ortadan kalkar, ne zamanla bir şeye dönüşebilir ve ne de eskiyebilir." 30

Bu düşünceyi, "Üslûp düşüncenin dış görünüşüdür", diyen Schopenhaure (d.1788-ö.1860)'dan ${ }^{31}$; "İnsanın özü dilinde ve hassâsiyetlerinde gizlidir." diyen Max Jacob (d.1876-ö.1944)'a ${ }^{32}$ ve "Üslûp, eşyayı değerlendirmede mutlak bir yoldur." şeklinde formüle eden Gustave Flaubert (d.1821-ö.1$880)^{\prime} \mathrm{e}^{33}$ varıncaya kadar, Buffon'dan sonra gelen pek çok önde gelen edebiyat tenkitçisi ve üslûp teorisyeni tercih etmiştir. Böylece üslûba tanım getirme düşüncesi, insanın şahsiyetine ilişkin gizli ve aşikar sırlarını ortaya koyan Psikiyatride kullanılan kişilik analiz kartları haline gelmiştir. ${ }^{34}$

28 el-Meseddî, el-Üslûbiyye ve'l-üslûb, s. 59.

29 Azzâm, el-Üslûbiyye, s. 23.

30 el-Meseddî, el-Üslûbiyye ve'l-üslûb, s. 63.

31 Arthur Schopenhaure, 1788-1860 yılları arasında yaşamış ünlü Alman irrasyonelist düşünürü. Temel eserleri: Die Welt als Wille und Vorstellung ( İrade ve Tasarım Olarak Dünya), Über die Vierfache Würzel des Zatzes wom Zureichende Gründe (Yeter Sebep İlkesinin Dörtlü Kökeni Üzerine), Die Beiden Grundprobleme der Ehtik (Ahlakın İki Temel Problemi) olan Schopenhaure felsefesinin temel tezi, esas gerçekliğin Kantçı kendinde-şey olduğu düşüncesinden meydana gelir. Bkz. Cevizci, Ahmet, Paradigma Felsefe Sözlüğü, Paradigma, İst. 1999, s. 759, 760.

32 Max Jacob Fransız hikayeci ve şair. İngiltere'de Yahudi bir ailede dünyaya geldi. Daha sonra Hıristiyan oldu. İkinci Dünya Savaşı günlerinde Drancy'ye sürüldü ve orada öldü. Le Laboratoire Central ve Méditations Religieuses, eserlerinden bazılarıdır. Bkz.el-Meseddî, el-Üslûbiyye ve'l-üslûb, s. 242.

33 Gustave Flaubert Fransız yazar. İnsan ruhunu çeşitli halleriyle tasvire çalıştı. Düşüncesi şu şekilde özetlenebilir: İbare düşünceye yaklaştıkça ona tutunur, ona tutundukça estetik boyutu artar. Başlıca eserleri: Salammbô ve Madame Bovary'dir. Bkz.el-Meseddî, el-Üslûbiyye ve'lüslûb, s. 247.

34 Azzâm, el-Üslûbiyye, s. 23. 
Bu ontolojik tanımın sonuçlarından bir tanesi de üslûbun insana bahşedilen tabiî bir özellik olmasıdır. Üslûp, Paul Claudel (d.1868-ö.1955)'in ${ }^{35}$ benzetmesiyle "şahsiyetin ses tonudur." Tıpkı kişinin ses tonunun başkasının ses tonuna benzememesi gibi, üslûbu da başkasının üslûbuna benzemez. ${ }^{36}$

Üslûbu yazarın dehasıyla ilişkilendiren yaklaşımlar da ortaya çıkmıştır. Bunlara göre ise üslûp, "araştırmacının ancak sezgisel yolla nüfuz edebilece$\breve{g i}$, bundan dolayı da hissedilen ama ifade edilemeyen karakteristik bir kıvllcımdır." Bu yaklaşımda Max Jacob (d.1876-ö.1944)'un düşüncesine doğru bir kayış gözlenir. Zira Jacob’a göre, yazarın eserini kaplayan bir kapalılık hissettiğimizde, ancak onun bir üslûbu olduğundan söz edebiliriz. ${ }^{37}$ Üslûbu yazarın dehasıyla örtüştüren bu anlayış, üslûbun oluşum sürecinde "bilince dayalı" bir süreç olup olmadığı tartışmasını da beraberinde getirmiştir. Kimilerine göre üslûp, edibin eserini dokuduğu $i b d \hat{a}^{38}$ sürecinde; ortaya çıkışından, teşekkülüne oradan kemale erişine kadar, idrakin eşlik etmediği, bilince dayanmayan bir olgudur. Nitekim Proust (d.1872-ö.1922) buna dayanarak üslûbu, "silinmez, yok edilmez bir tasdik gibi olan, söylemin ifade tarzına ait parmak izi" olarak formüle etmiştir. Mounin ${ }^{39}$ ve Deloffere'den her biri de bu formülasyonu benimsemişlerdir. Söz konusu bakış açısı, üslûbun sahibiyle olan organik ilişkisine dair düşünce derinliğini ortaya koymaktadır. Öyle ki sanki üslûp yazara ait bir mühür ya da imza konumundadir. ${ }^{40}$

Bazıları da yazarın şahsiyetine ulaşmak için üslûp analizi yapılarına tatbik ettikleri, üslûp ölçütü niteliğinde istatistiksel bazı kriterler çıkartmaya çalışmışlardır. Burada karşımıza üslûbu, tecrübenin sübjektifliği ile iletişimin gerekleri yani kişisel olgu ile toplumsal şuur arasında, ortada bir yerde tanımlayan Starobinski çıkar. ${ }^{41}$

35 Paul Claudel Fransız şair ve romancı. Pek çok siyasi makamda bulundu. 18 yaşında Hıristiyan oldu. Edebî çalışmalarında dîni duyguları ağır basar. Bkz.el-Meseddî, el-Üslûbiyye ve'l-üslûb, s. 249.

36 el-Meseddî, el-Üslûbiyye ve'l-üslûb, s. 64.

37 el-Meseddî, el-Üslûbiyye ve'l-üslûb, s. 65.

38 İbdâ bir edebiyat terimi olup, "yaratma" demektir. Yani mevcut malzemeyi kullanarak, Yaratan'ı değil de 'yaratış'ı taklit ederek daha önce örneği olmayan, yeni bir şey ortaya koyma faaliyetidir. Bkz. Karataş, Edebiyat Terimleri Sözlüğü, s. 212; 513.

39 Georges Mounin 1910'da doğdu. Fransız Dilbilimci ve münekkit. Eserlerinin çoğunluğu genel ve özel dilbilim olgularına giriş niteliğindedir. Introduction à La Sémiologie ve Clefs Pour Le Linguistique eserlerinden bazılarıdır. el-Meseddî, el-Üslûbiyye ve'l-üslûb, s. 250, 251.

40 el-Meseddî, el-Üslûbiyye ve'l-üslûb, s. 66.

41 Azzâm, el-Üslûbiyye, s. 24. 
Yukarda işaret ettiğimiz, üslûbun doğuşu ve teşekkülüyle bilinçsiz bir süreç olduğu tezine karşı tez olarak ortaya çıan; üslûbu, dilin sahip oldu$\breve{g u}$ imkan ve güçler üzerinde yazarın yaptığı bilinçli bir seçim olarak görenler de olmuştur. Bu bilinçli seçim tezi, ibdâ olgusuna dair ileri sürülen, "deha", "ilham" ya da "kişisel doğuş" tezlerini çürütür. Nitekim Spitzer (d.1887-ö.1960), ${ }^{42}$ üslûbun dil araçlarına yönelik pratik ve metodik uygulama olduğunu vurgulamıştır. J. Marouzeau "Yazılı ya da sözlü anlamda dil kullanıcısının kendisine sunulan dil imkanları karşısında takındığı tavrıdır." şeklinde tanımlamıştır. G. Von der Gabelentz bu tecrübî düşünceyi tetkik eder ve şu sonuca varır: "Üslûp, dil kullanımının belirli bir anında, insanın dil imkanlarının birini diğerine tercih etmesini içerir." 43

M. Cressot üslûp olgusunun ortaya çıkışılla, dilin genel olarak iletişimde kullanılma esası arasında karşılaştırma yapar ve seçim kanunun, sanata ilişkin olguyla sınırlı olmadığını, onun genel olarak iletişim sisteminde, kaynak birimle hedef birim arasında bir anlaşmadan; müşterek şuurdan oluşan bir anlaşmadan ibaret olduğu sonucuna ulaşır. ${ }^{44}$

Kaynak birim/yazar merkezli üslup tanımına ilişkin bu objektif akımı oluşturan etkenler ortaya konulduğu zaman, ortaya çıkmıştır ki, seçme düşüncesi, beraberinde epistemolijik olarak iki prensibi kabul etmedikçe, doğru olmayacaktır. Bunlar; seçimi ortaya çıkartan sâikler ve seçimin icra ettiği fonksiyonlar. Dilin imkan ve araçları içerisinde hareket etmekte olan kaynak birim, kendisini organik bir şekilde iletişim konusunda gereklerini yerine getirmeye bağlayan uyarıcılara karşı geri ileti verecektir. Daha sonra kaynak birim mesajını, doğrudan ve dolaylı yolarla yükleyecek bunu yaparken de söylemin içeriği ile hedef birim üzerinde etki uyandıracak özgünlükleri (parmak izlerini) birbiriyle irtibatlandıracaktır.

Görüldüğü üzere bu kesim, metinle, metni inşâ edenin karakterine ait özellik ve unsurların, imâl-i fikir ya da inşâ aşamasında dilin kullanımına yansımasını ve tesirde bulunmasını kayda değer bulmuş ve üslûp tanımlarını bu çerçevede yapmışlardır.

42 Léo Spitzer. Avusturyalı dilbilimci ve edebiyatbilimci. Yenibiçimcilikle yapısalcılı̆̆ın öncüleri arasında yer alır. Dilbilim ve üslûp araştırmalarıyla tanınır. 1913-1936 yılları arasında İ.Ü. Edebiyat Fakültesinde Batı Dilleri ve Edebiyatları Bölümünde görev yapmış, bazı Türk Dilbilimcileri ve Edebiyat bilimcileri üzerinde de etkili olmuştur. Stilstudien (Üslûp İncelemeleri), Essays in Historical Semantics (Tarihsel Anlambilim Üzerine Denemeler), Linguistics and Literray History (Dilbilim ve Edebiyat Tarihi) eserlerinden bazılarıdır. Bkz. Vardar, Açıklamalı Dilbilim ve Dilbilgisi Terimleri Sözlüğü, s. 194.

43 el-Meseddî, el-Üslûbiyye ve'l-üslûb, s. 72.

44 el-Meseddî, el-Üslûbiyye ve'l-üslûb, s. 72. 
Kısaca bu yaklaşımı benimseyenlere göre üslûp; inşâ sahibinin, dili kullanım tarzı ve dilin imkanları üzerindeki tasarrufudur. Bir başka tabirle, belirli bir durumu ifade amacıyla, belirli dil özellikleri ve unsurlarını seçerek kullanmasıdır." 45

Şimdi de Batıda ortaya çıkan hedef birim/okur merkezli üslûp tanımları üzerinde kısaca duralım.

b) Hedef birim/Okur Merkezli Tanımlar: Üslûp incelemeleri dilsel olduğu kadar psikolojik ve sosyolojiktir de... Bu yüzden bir çocukla yetişkin birisiyle konuştuğumuz gibi ya da kültürlü bir kimseyle cahil birisiyle konuştuğumuz gibi konuşmayız. Anlatımda, hedef birimin dile ilişki algısını dikkate almak tek etken değildir. Aynı zamanda toplumsal hiyerarşi de işin içine girer ve bizi ifade tarzımızı değiştirmeye mecbur eder. Önemli bir kimseyle bizimle aynı konumda olan birisiyle konuştuğumuz şekilde konuşmayız. Yabancı bir kimseyle olan konuşmamız, bir yakınımızla olan konuşmamız gibi olmayacaktır. Hedef birimle aramızda mevcut olan toplumsal fark aracılığıyla, tavrımızda değişiklik yapmamıza yol açan husus da bu şartlardır. ${ }^{46}$

Bazı dilciler bu durumu, kaynak birimin muhatabında, tecrübesini söylemi aracılığıyla yaşatma arzusu şeklinde açıklamaya çalışmışlardır; kaynak birim, hedef birimin sadece mesajını anlamasını değil, aynı zamanda yaşadığı tecrübeyi de yaşamasını istemektedir. ${ }^{47}$

Daha açık bir ifadeyle, muhatabın tabiatı, kişiliği ibdâ ameliyesinin içindedir. Bu, durum kuşkusuz, ibdâ sahibinin beyan gücüne göre, hedef birimi kendi içinde bulunduğu/ yaşadı̆̆ı ruh haline taşımaya çalışmasıyla ya da başka bir ifadeyle kendisini 'ibdâ'ya yönelten tecrübeyi muhatabına yaşatmaya çalışmasıyla alakalıdır. ${ }^{48}$

Araştırmacılar üslûba, kaynak birimin, muhatabının tasarruf hürriyetini elinden alan, muhatap üzerine hakim kıldığı bir basınç gücü gözüyle ele almışlardır. Sanki üslûp, hedef birimin kelimelerden oluşmuş bir komutanı gibidir. ${ }^{49}$

Bu tür bir verinin ortaya çıkması çağdaş üslûpbilimin ortaya çıkmasından çok önceye rastlar. Nitekim Stendhal (d.1783-ö.1842) ${ }^{50}$, üslûbun özü-

45 Bkz. Maslûh, Sa'd, el-Üslûb:dirâse lügaviyye ihsâiyye, Dâru'l-buhûsi'l-ilmiyye, Kuveyt 1980, s. 23, 29. Krș. el-Ma'tûk, "Mefûmu'l-üslûb", s. 6.

46 Abdulmuttalib, Muhammed, el-Belaga ve'l-üslûbiyye, eş-Şeriketu'l-Mısrıyye, Kahire 1994, s. 234, 235.

47 Azzâm, el-Üslûbiyye, s. 24.

48 Abdulmuttalib, el-Belaga ve'l-üslûbiyye, s. 235.

49 Abdulmuttalib, el-Belaga ve'l-üslûbiyye, s. 235.

50 Ünlü Fransız romancısı. İlk romanı Armance'ı kırkdört yaşında yazdı. Aşk üzerine yazdığı romanı hakkında, "yüz kişi okusun yeter" diyordu. Eser on yılda on yedi okuyucu bulabildi. Romancı, kitabının bir gemi ambarında safra gibi kullanıldığını söyler. Meriç'in tespitine göre, 
nün, düşünceye kattı̆̆ şeyde gizli olduğunu söyler. Flaubert (d.1821-ö.1880) ise üslûbu, düşünceye eşlik eden ve hedef birimi vuran bir ok olarak niteler. Paul Valéry (d.1871-ö.1946) ${ }^{51}$ ise, üslûbun anlamıyla, ibarenin etkili hükümranlığını birbiriyle örtüştürür. Çağdaş üslûpbilim öncüleri bu veriyi üslûbun tanımı noktasında neredeyse temel bir esas olarak kabul etmişlerdir. Nitekim P.Guiraud ${ }^{52}$ üslûbu, okuru ikna etmek, hoş vakit geçirtmek, dikkatini çekmek ve hayal gücünü harekete geçirmek için söylemin büründügü renkler cümbüşü olarak tanımlar. De Laffer, üslûbun bizi hakimiyeti alttna alan ibarenin hükümdarı olduğu noktasında ssrar eder. ${ }^{53}$ Riffaterre ${ }^{54}$ gelir ve bu bakış açısını geliştirmek suretiyle bilimsel objektivizme daha yakın hale getirir. Öyle ki Riffaterre üslûp tahlilini yapacak kişiye, doğrudan metinden değil, okurun metin etrafında oluşturduğu hükümlerden hareket etmesini şart koşar. Dedektif okur adını verdiği, üslûp istatistiğinin kaynağı konumunda gördüğü okura itimat etmeye çağırır. Yaklaşımına göre; analizci, bu dedektif okurun ortaya attığı kriter hükümlerin tamamını, metin içindeki gizli uyaranların ortaya çıkarttığı bir tür geri ileti şeklinde kabul ederek ele alır. Her ne kadar bu hükümler sübjektif değerlendirmelere dayansa da, hükümlerin, dayandıkları sebeplerle ilişkilendirilmesi objektif bir yaklaşımdır. Bu da hiçbir şekilde, söz konusu hükümleri estetik açıdan haklı çıkarmakla ilgilenmeyen analizcinin görevidir. ${ }^{55}$

Bu yaklaşımda, metin ya da sözle, metnin muhatabı arasındaki ilişkinin önemine, muhatabın konumuna, muhatapta ortaya çıkan tepki ve bu tepkinin önemine vurgu yapılmıştır. Bu zaviyeden hareketle üslûbu, söz dizimine ait bazı unsurları ön plana çıkarmak ve okurun dikkatini bu unsurlara

Stendhal bir anatomi masası, roman iç dünyanın sokaklarında dolaştırılan bir ayna. Edebiyatın musiki olduğu bir çağda neşter gibi bir üslûp kullanmıştır. Bkz. Meriç, Cemil, Jurnal, İletişim Yay., İstanbul 1993, II. 33, 55.

51 Paul Valéry (d.1871-ö.1946) Fransız edebiyatçısı. Oldukça iyi bir eğitim almış, edebiyat dışında da geniş bir birikime sahiptir. Dil ve tenkit meseleleri üzerinde durmuş, Fransa'da hocalık yapmıştır. Geride bıraktığı en meşhur eser Cahiers'tir. Bu sayede, dil felsefesi ve edebiyat konusunda önde gelen isimlerden birisi olarak kabul edilmiştir. Bkz. el-Meseddî, el-Üslûbiyye ve'l-üslûb, s. 246.

52 Pierre Guiraud, Fransız dilbilimci ve edebiyat doktoru. Nice ve Vancouver Üniversitelerinde dilbilim dersleri verdi. Dilbilimin pek çok dalında giriş niteliğinde eserler verdi. Bunlardan bazıları: La Stylistique, La Sémantique ve La Grammeirctir. Bkz. el-Meseddî, el-Üslûbiyye ve'lüslûb, s. 248.

53 Azzâm, el-Üslûbiyye, s. 25. Krş. Abdulmuttalib, el-Belaga ve'l-üslûbiyye, s. 237, 238.

54 Michael Riffaterre, ABD.'nin en önemli üniversitelerinden birisi olan Colombia Üniversitesinde hocalık yapmıştır. 50'li yılların başından itibaren üslûpbilim incelemelerinde ihtisaslaşmıştır. En önde gelen eseri, Essais de Stylistique Structuraledir. Bkz. el-Meseddî, el-Üslûbiyye ve'lüslûb, s. 243.

55 Azzâm, el-Üslûbiyye, s. 25. 
çekmek suretiyle okurun hassâsiyeti üzerinde hakimiyet kuran etkin bir güç olarak tasavvur etmişlerdir. Yaklaşımın özü, okurla metnin ifade yapısı arasındaki ilişki ve ifade yapısının okur üzerinde meydana getirdiği etki, şeklinde özetlenebilir. ${ }^{56}$

c) Söylem/Eser Merkezli Tanımlar: Metin, metin yazarının çocuğu, üslûp ise metnin çocuğudur. Bu yüzden üslûp yazarından ayrılabilir. Aralarındaki bağ, ibdâ ve ritim anında mevcuttur. Üslûp, kaynak birim düşüncesine göre, kaynak birimin düşünce ve kişiliğinin şualarının yansıdığı levhadır. Hedef birim düşüncesinde, hedef birim tarafından açılacak kapalı bir mektuptur. Söylem düşüncesine göre ise, söylemin kendisi için var olan bir şeydir. ${ }^{57}$

Üslûbun mahiyetine ilişkin tanım kaynağını, öne çıkmış özellikleri bakımından dile ilişkin olguyu oluşturan unsurlardan alır. Charles Bally (d.1865ö.1947) üslûbu üslûpbilimden ayrı tutar. Bally üslûbun anlamını, dilin içinde gizli anlatıma ilişkin potansiyelin, farazi düzlemden varlık düzlemine çıkmasıyla sınırlamıştır. Bally'nin tasavvuruna göre üslûp, kullanımın bizzat kendisidir. Sanki dil, her biri ayrı anlam yükleri topluluğu, üslûpsa sanki bir dil laboratuarında bunları reaksiyona sokan unsurdur. ${ }^{58}$

Bu açlım İsviçreli Dilbilimci Bally'ye ait nazariyenin çocuğudur. Pek çok üslûpbilimci, ister Bally'den doğrudan etkilenip daha sonra nazariyesini geliştirmiş olsun, isterse tenkite ilişkin prensiplerini, Bally'nin nazariyelerinin ortaya koyduğu yapısalcı metotlardan almış olsun, bu düşüncede bir araya gelmişlerdir. Burada metnin yapısal düzenine ait özelliklere dayanarak üslûbu tanımlama metodu ortaya çıkmıştır. ${ }^{59}$

1948 senesinde R. Wellek ${ }^{60}$ ve A. Varren ${ }^{61}$ ikilisi karakteristik özelliklere dayanarak, üslûp sınıflarının çeşitliliğine dair nazariyelerini formüle etmişlerdir. Üslûbun, kelimelerin eşya ile olan ilişkisi açısından tanımlanabileceği görüşünü ileri sürmüşler; ardından da aynı şekilde, kelimeleri birbirine bağlayan unsurlar ve kelimeler topluluğunun, dil aygıtıyla olan ilişki-

56 el-Ma'tûk, "Mefûmu'l-üslûb", s. 7.

57 Azzâm, el-Üslûbiyye, s. 26, 27; el-Meseddî, el-Üslûbiyye ve'l-üslûb, s. 84.

58 Azzâm, el-Üslûbiyye, s. 27; el-Meseddî, el-Üslûbiyye ve'l-üslûb, s. 85.

59 el-Meseddî, el-Üslûbiyye ve'l-üslûb, s. 85, 86; Azzâm, el-Üslûbiyye, s. 27.

60 René Wellek, Avusturyalı. 1903'de Viyana'da doğdu. Daha sonra ABD.ye yerleşmiş ve Yale Üniversitesi bașta olmak üzere çeșitli üniversitelerde ders vermiștir. Başlica eserleri: Theory of Literature (A. Varren ile müssterek), The Rise of English Literary History ve A History of Modern Criticism'dir. Bkz. el-Meseddî, el-Üslûbiyye ve'l-üslûb, s. 253.

61 Austin Varren, Amerikalı.1899 yılında Waltham'da doğdu. 1926'da Princeton'da doktorasını tamamladı. Iowa ve Michigan Üniversitelerinde İngiliz Dili ve Edebiyatı okuttu. Wellek ile birlikte Theory of Literature adlı eseri kaleme aldı. Bkz. el-Meseddî, el-Üslûbiyye ve'l-üslûb, s. 246. 
leri bakımından tanımlanabileceğini ileri sürmüşlerdir. ${ }^{62}$ Daha sonra, A. Hill ve Hjelmslev (d.1899-ö.1965)'den ${ }^{63}$ her biri tanıma ilişkin bu kıstası tarihsel metodundan bağımsız hale getirmişlerdir. Hill üslûbu, sadece cümle düzeyinde değil, daha geniş bir düzeyde; metin ve söz düzeyinde mevcut olan dil unsurları arasındaki ilişkilerin taşımış olduğu mesaj olarak tanımlamıştır. Hjelmslev ise, üslûbun anlamını metnin bütünsel yapısını içine alacak şekilde genişletmiştir. Öyle ki üslûbun bizzat kendisi de bir iletişim aracı haline gelmiştir. ${ }^{64}$

Sonra Jakobson (d.1896-ö.1982) ${ }^{65}$ gelmiş, edebî metni, söze ilişkin şiirsel fonksiyonun ağır bastığı bir söylem olarak tanımlamıştır. Edebî metne dair tanımı, üslûbun tanımına, 'merkezi fonksiyonel organisazyon' kaydını getirmiştir. Bu yüzden, Jakobson'a göre metin, kendisi için ve kendi içinde oluşan bir söylemdir. ${ }^{66}$

Starobinski, 1972 yılında bu nazariyenin ayrıntılarını tespit etmeye çalışır. Böylece üslûbun, edebî metnin iç dünyasını düzenleyen kanunun bir tetkik aracı olduğunu ortaya koyar. ${ }^{67}$

Bu esasa göre üslûp çalışması, iletişim sistemini oluşturan unsurların, ekleme ve çıartma yoluyla çözümlenmesine dayanır. Böylece benzerlik ve farklılıklar tecrübi bir şekilde ortaya çıkar. Üslûbun mahiyetinin rasyonelleştirmesine yönelik bu yaklaşım, dilbilimsel, sanatsal bir olgu olarak,

62 el-Meseddî, el-Üslûbiyye ve'l-üslûb, s. 87; Azzâm, el-Üslûbiyye, s. 27.

63 Louis Hjelmslev (d.1899-ö.1965). Kopenhag Dilbilim Çevresi'ni ve glosematiği kuran Danimarkalı dilbilimci. Hjelmslev'in oluşturduğu dil kuramı öncekilere kıyasla çok daha biçimsel ve soyut nitelikte olup, felsefeyle mantığa da büyük oranda yer verir. Dili kendisine özgü bir yapısı olan, yeterli ve tutarlı bir bütün olarak ele alır. Kendisinden önceki çalıșmaları sübjektif, kesinlikten yoksun ve bundan ötürü de bilimsellikten uzak olarak niteleyerek dil kuramına sağlam ve katışıksız bir çerçeve sunmak gayesini güder. Ona göre dil bir cevher değil, bir biçimdir. Her düzlemde cevher/biçim karşıtlığını öngörür. Prolegomena to a Theory of Language adlı eseriyle dilbilim çevrelerinin ilgisini çeker. Le Lange une Introduction, Essais Linguistiques eserlerinden bazılarıdır. Bkz. Vardar, Açıklamalı Dilbilim ve Dilbilgisi Terimleri Sözlüğü, s. 119. 64 el-Meseddî, el-Üslûbiyye ve'l-üslûb, s. 87, 88; Azzâm, el-Üslûbiyye, s. 28.

65 Roman Jakobson (d.1896-ö.1982). Rus kökenli ABD'li dilbilimci. İşlevsel Dilbilimin önde gelen teorisyenlerindendir. Ülkesinden ayrılarak Prag Üniversitesi'nde öğretim üyeliği yaptığı 20’li yıllarda Prag Dilbilim Çevresi'ni kuranlar arasında yer alan Jakobson, yapısal dilbilimin oluşmasına büyük katkıda bulunmuş, yapısalcılığın değişik alanlara yayılmasını sağlayan çalışmalar yapmıștır. 1939'da ABD'ye göç ettikten sonra çok yönlü etkinliklerde bulunmuş, dilbilimde olduğu gibi edebiyatbilim, iletişimbilim kuramını, sinirdilbilimi yeni doğrultulara yönelten çalışmalar içine girmiștir. Eserlerinden bazıları: Essais de Linguistique Générale (Genel Dilbilim Denemeleri), Questions de poétique (Edebiyatbilim Sorunları), Studies in General and Oriental Linguistics (Genel Dilbilim ve Doğu Dilbilmi Üstüne İncelemeler) Bkz. Vardar, Açıklamalı Dilbilim ve Dilbilgisi Terimleri Sözlüğü, s.131.

66 Azzâm, el-Üslûbiyye, s. 28; el-Meseddî, el-Üslûbiyye ve'l-üslûb, s. 88, 89.

67 el-Meseddî, el-Üslûbiyye ve'l-üslûb, s. 88, 89; Azzâm, el-Üslûbiyye, s. 28. 
özelliğini muhafaza ederek tenkit ve edebiyattaki yapısalcı metoda yaklaşır.

Söylem merkezli yaklaşımda, metni inşâ edenin de metnin muhatabının da bir tarafa bırakılması gerektiği görüşü ileri sürülmüş, metni bağlam itibariyle kendisine benzer bir metinle karşılaştırmak, yahut kıyas etmek sûretiyle metnin bizzat kendisine, tavsifine ve değerlendirilmesine önem verilmesinin zarureti üzerinde durulmuştur. Sonra, metne katılan; standart dil kullanımını aşan yeni unsurlara ve tercih edilmiş dil özelliklerine bakılmalıdır. Bunların ışığında üslûbu, standart dil kullanımının dışına çıkmak yahut söz konusu standarda yeni ilave yapmak ya da ortam ve bağlama göre çeşitlilik arz eden dil özelliklerine ilişkin hususiyetler şeklinde görmüşlerdir. ${ }^{68}$

Bazı araştırmacılar bu üç yaklaşım arasında ortak bir payda olduğu görüşündedirler. Söz konusu ortak payda: "Üslûbu, dile ait bir takım imkan ve ihtimaller varken, diğer bir kısım kullanıma sunulmuş imkan ve ihtimalleri tercih etmeyi ve buna vurgu yapmayı temel alan, dile ait özel bir kullanım olarak kabul etmektir. Kullanımı belirleyen temel temyiz vasıtası ise, doğrudan ya da dolaylı yapılan mukayesedir." ${ }^{\prime 69}$

Yukarıda geçen görüşlerden hareketle şunları ifade edebiliriz: Her ne kadar üslûp kavramı kadim araştırmacıların çoğunluğuna göre, sözün ifade yapısı ve şekline ilişkin dilsel niteliklerle irtibatlı olsa da, Batılı araştırmacılar üslûba ilişkin standardize edilmiş, sabit bir kavram ya da anlama ulaşamamıştır. Modern Batı Edebiyatına gelince; üslûp sınırları belli lafzî bir çerçeve içerisinde ifade edilmekten ziyade dal budak salmış, daha karmaşık, daha kompleks hale gelmiştir. Muhtemelen, üslûpbilim ya da üslûp ilminin ortaya çıkması ve olgularının gelişmesi bu etkenlerin sonucu olmuştur. Üslûp ve üslûp bilim konusunda yapılan tekliflerin çokluğuna rağmen üslûp kavramı, düşüncelerin, gerisindeki sırrı çözmek ve hakikatine ermek için adeta nefessiz kaldığı, çözülmesi zor bir muamma olarak kalmaya devam etmektedir. ${ }^{70}$

Her ne kadar üslûp konusu, Batı Edebiyatında, Arap Edebiyatında olduğundan çok daha fazla önemli bir yere sahip olmuş hatta bağımsızlı̆̆ını ilan etmiş olsa da, üslûbun tanımına, tahliline, bağlantılarına ve ilişkilerine dair Batı Edebiyatında görmüş olduğumuz bu keşmekeş ve tereddütleri Arap Edebiyatında da görmekteyiz. ${ }^{71}$

68 Maslûh, el-Üslûb, s. 30. Aynı șekilde bkz. s. 27; el-Ma'tûk, "Mefûmu'l-üslûb”, s. 7.

69 Maslûh, el-Üslûb, s. 33; el-Ma'tûk, "Mefûmu'l-üslûb”, s. 7.

70 el-Ma'tûk, "Mefûmu'l-üslûb", s. 7.

71 el-Ma'tûk, "Mefûmu'l-üslûb”, s. 7. 